\title{
BANCOS E CRÉDITO NO DESENVOLVIMENTO RECENTE DA BAHIA ${ }^{1}$
}

\author{
Elsa Sousa Kraychete
}

\begin{abstract}
A partir da distribuição espacial das agências bancárias e indicadores de depósitos e créditos, o artigo apresenta a geografia financeira do estado da Bahia em 2005. Para fundamentar a leitura dos dados, recupera-se a trajetória recente da economia baiana, destacando-se, em seguida, o papel dos bancos e o aporte do crédito como fundamentais para o desenvolvimento regional. Por fim, com base em dados do Banco Central, apresenta-se a posição relativa da Bahia frente às principais praças bancárias brasileiras, a rede de agências, a cobertura do território baiano por agências bancárias, a distribuição espacial dos estoques médios de depósitos e créditos e a hierarquização financeira das principais praças. Dessa forma, o artigo busca estabelecer os nexos entre a dinâmica financeira regional e a reespacialização dessas atividades, associadas à natureza dos ciclos de acumulação da economia.

Palavras-Chave: desenvolvimento, território, bancos, crédito, Bahia.
\end{abstract}

Este artigo analisa a espacialização do sistema bancário e financeiro do estado da Bahia, cujos contornos e fundamentos acompanham as tendências evolutivas da economia baiana, marcadas por diferentes ciclos de acumulação e desenvolvimento: primeiramente, aquele relativo à transição de uma economia regional de base agroexportadora para um projeto de industrialização e modernização nacional, entre os anos 1960-1980; em seguida, o que se manifesta pelas redefinições e ajustes dos anos noventa, caracterizados pela integração globalizada do sistema financeiro internacional, apoiado na abertura comercial e na redefinição de atores econômicos sustentados por novas tecnologias eletrônicas.

\footnotetext{
* Doutora em Administração pela Universidade Federal da Bahia. Professora Permanente do Programa de Pós-Graduação em Planejamento Territorial e Desenvolvimento Social da Universidade Católica do Salvador. Av. Anita Garibaldi, 2981 - Rio Vermelho. Cep: 41.940450 - Salvador - Bahia - Brasil. elsask@ucsal.br

${ }^{1}$ A pesquisa que dá origem a este texto contou com a participação de José Williams Soares da Silva, bolsista de Iniciação Científica da Fundação de Amparo à Pesquisa do Estado da Bahia.

Agradeço a Anete Brito Leal Ivo a atenta leitura e sugestões para tornar este texto mais claro.
}

Essa evolução implicou inflexões e movimentos diferentes na rede bancária. Inicialmente, houve uma tendência à ampliação das agências pelo estado e, posteriormente, um movimento de retração e relocalização de agências, acompanhando o processo de concentração de capitais e seguido da redefinição de espaços das agências e da natureza das instituições públicas e privadas do sistema bancário e financeiro, no âmbito nacional, e que teve especificidades no estado da Bahia.

Em que cenário e ambiente econômico essas mudanças, ajustes e relocalização das agências bancárias ocorrem na Bahia? Quais as tendências espaciais que a relocalização das atividades e da rede de serviços bancários apresentam para o estado da Bahia? Que nexos a evolução mais recente e a relocalização da rede bancária no estado mantêm com as singularidades de estruturação da economia baiana? Essas são algumas questões que este artigo buscará analisar. Para responder a tais indagações, este artigo está estruturado em quatro seções, além desta introdução. A primeira recupera os marcos do desenvolvimento econômico da Bahia nas últimas décadas. A segunda analisa o papel 
de dois bancos públicos na sustentação financeira desse processo de desenvolvimento, além de apresentar dados sobre a estrutura bancária no estado, em 1988. A terceira parte apresenta a rede bancária, a cobertura bancária do território baiano e a distribuição espacial dos estoques médios de depósitos e de créditos. Por fim, na quarta e última parte, são apresentadas as considerações finais.

\section{MARCOS DA TRAJETÓRIA DO DESENVOLVI- MENTO ECONÔMICO DA BAHIA E A SUA DIMENSÃO ESPACIAL ENTRE 1950 E 2005}

De um modo geral, a dinâmica espacial da rede bancária no estado da Bahia acompanha três momentos específicos com imbricações temporais e espaciais: o primeiro caracteriza-se pela existência de bancos com capital e atuação regional, gerados pelo ciclo de desenvolvimento econômico agroexportador do estado e diretamente associados a ele. São exemplos dessa fase o Banco da Bahia e o Banco Econômico da Bahia. Uma segunda fase, entre o período de 1940-50, corresponde ao ciclo de crise e transição do modelo agroexportador e implementação de um projeto de desenvolvimento com base na industrialização, na modernização da agricultura e num projeto de integração do espaço nacional. Nesse momento, observa-se uma tendência crescente de expansão e ampliação da rede de bancos, iniciada em meados da década de sessenta e que perdura até os anos oitenta. O terceiro, finalmente, que se inicia na década de noventa, é caracterizado por uma relocalização das atividades financeiras e bancárias com uma maior redução de agências e concentração espacial de agentes econômicos e capitais a partir das mudanças relacionadas à abertura comercial e financeira do país.

Com base no mapeamento das agências bancárias no estado da Bahia e da movimentação financeira dessas agências (a partir dos volumes de depósitos e créditos), este artigo caracteriza a dialética e as relações paradoxais. Tal atividade apresenta movimentos contraditórios que associ- am um padrão integrado e de concentração, de um lado, mas, ao mesmo tempo, diferenciado espacialmente, com tendências não lineares sobre o espaço nacional. Ou seja, a configuração que assumiu o sistema financeiro nacional de meados de sessenta até o início dos anos 90 apresenta movimentos que, se, por um lado, resultam num processo de concentração bancária e financeira, por outro, tal concentração não se contrapõe a uma expansão da rede de agências para além da Região Sudeste.

Observando-se a dinâmica dos ajustes e mudanças do sistema bancário, verifica-se que, a partir de meados dos anos 1960, a reforma do sistema bancário buscou romper os limites colocados por uma modalidade de intermediação financeira baseada na preponderância do tradicional esquema de captação de depósitos, por um lado, e na oferta de crédito como a fonte central de aplicação, por outro. Avançar na direção do financiamento da expansão econômica requereu a ordenação do sistema financeiro em termos de ampliação das suas funções, mas também a disciplina quanto ao crescimento da rede bancária.

Esse processo continha, portanto, a contradição de concentrar a maior parte dos investimentos em determinados espaços, quando o modelo de desenvolvimento vigente demandava a sua extensão para além da região central, de forma a dar sustentabilidade à política de modernização e integração do desenvolvimento nacional. Os bancos, afinal, cumpriam fundamental papel na implementação da política econômica desenvolvimentista do governo brasileiro. Os incentivos fiscais, principal instrumento de intervenção governamental nos sistemas produtivos regionais, e a ampliação da oferta de créditos supunham a presença de agências bancárias. Por outro lado, a expansão do sistema de arrecadação também demandava a oferta de serviços bancários de cobertura ampla.

Na década de setenta, a expansão da implantação de agências, segundo Corrêa (2006), estava condicionada por dois movimentos: (i) o de atuação do Estado como articulador de políticas 
que visavam à promoção da integração nacional, moldada de forma a alargar a atuação dos agentes financeiros públicos sem concorrer diretamente com os intermediários financeiros privados; e (ii) o da expansão dos bancos privados, que ampliaram a oferta de empréstimos, sustentados no ganho inflacionário decorrente da operação de captação de depósitos à vista não remunerados.

Essa dupla tendência acarreta importantes modificações no sistema bancário. Por um lado, promove a desregionalização ${ }^{2}$ do sistema financeiro, que até então operava com base em bancos regionais (Corrêa, 1989). Tais bancos não reuniam condições de implantação em praças mais distantes, o que acabou por determinar que a ampliação da rede bancária do país na direção de regiões periféricas ocorresse com base em bancos privados nacionais de grande porte ou nos bancos públicos, em especial, os estaduais.

Nesse sentido, em 1971, o Banco Central emitiu a Resolução 200/1971, que suspendeu a concessão de cartas patentes para novas agências, particularmente nas praças de São Paulo e Rio de Janeiro, e permitiu a ampliação da rede em outras regiões com a abertura de agências pioneiras (Hannequim, 1989; Amado, 1996).

Além do respaldo legal, a orientação de ampliar a rede bancária na direção das regiões mais distantes foi possível graças ao suporte do sistema de telecomunicações, oficialmente declarado como nacional desde 1972, o que possibilitou às agências bancárias operarem de forma integrada, com apoio nas diferentes redes de serviço de telefonia e transmissão de dados (Dias, 2005).

No início dos anos 1980, mesmo num contexto de crise, já era patente a ação do Banco Central, orientada para: estender a assistência bancária a todos os municípios; melhorar a assistência bancária de municípios menos atendidos; e efetuar medidas de regionalização bancária (Corrêa, 2006, p.179). Nessa conjuntura, os bancos combinam a estratégia de ganhos inflacionários com os

${ }^{2}$ Essa desregionalização refere-se à natureza do capital desses bancos de caráter local e significa uma maior integração do sistema bancário no âmbito nacional, no sentido de garantir uma maior cobertura. incentivos advindos do Banco Central e continuam a ampliação da rede de agências em todo o território nacional. As regiões Centro-Oeste, Norte e Nordeste, exatamente as que exibiam menores índices de desempenho econômico, expandiram suas redes em $56 \%$, 90\% e 92\%, respectivamente, entre 1979 e 1983. As regiões Sul e Sudeste, nesse mesmo período, viram as suas redes bancárias ampliadas em $25 \%$ e $16 \%$, respectivamente. O crescimento do número de agências nas regiões menos desenvolvidas, no entanto, não implicou perda de centralidade da Região Sudeste que, em 1983, detinha, aproximadamente, 46 \% do total de agências bancárias. A ampliação do número de agências resultou de uma estratégia na qual os intermediários financeiros públicos expandiram as suas participações nas praças menos assistidas. As regiões Norte e Nordeste, nesse momento, detinham 43\% das agências de bancos públicos. Para efeito de comparação, essas regióes concentravam apenas $21 \%$ do total nacional das suas agências de bancos de capital privado (2006, p.180).

No decorrer dos anos noventa, a conjuntura econômica passa a apresentar novos desafios para os bancos, demandando redefinições estratégicas. O controle da inflação, após o Plano Real, já não possibilitava a manutenção dos lucros pela via da captação não remunerada, ou a taxas menores que as de aplicação. A inflação controlada, no entanto, apontava para a necessidade de os bancos ajustarem-se a partir de mudanças na composição da estrutura de captação e aplicação. Mas nem todos alcançaram tal intento, resultando em perdas de receitas inflacionárias (Carvalho; Vidotto, 2007).

Nos trâmites que visavam ao ajuste do sistema, muitas dificuldades se impuseram, implicando quebras, fusões e incorporação de instituições financeiras, levando a mais uma reestruturação do setor financeiro. Em 1994, o Brasil contava com 230 bancos, reduzidos, quatro anos depois, a 179, demonstrando um processo de concentração bancária. Assim, entre 1995 e 1998, os cinquenta maiores bancos responderam, aproximadamente, por $98 \%$ do total do ativo, do 
patrimônio líquido, do número de trabalhadores e do número de agências no cômputo bancos (Gonçalves, 1999, p.163).

Em grande medida, a nova estrutura foi orientada pelo Programa de Estímulo à Reestruturação e ao Fortalecimento do Sistema Financeiro Nacional (PROER) e pelo Programa de Incentivo à Redução do Setor Público Estadual na Atividade Bancária (PROES). A reestruturação do setor financeiro levou a mudanças substanciais na propriedade do capital, seja a partir da abertura ao capital externo, seja pela liquidação ou venda dos bancos públicos estaduais.

A reestruturação do setor, no período, repercute espacialmente na elevação da participação da Região Sudeste, que passa de 50,73\% do total de agências para 54,38\%, entre 1990 e 2002, quando as demais regiões, à exceção da Região Sul (que permanece no mesmo patamar), perdem posição no ranking nacional, no mesmo período: a Região Norte cai de 4,29\% para 3,42\%; a Nordeste de $16,67 \%$ para 15,26\%; e a Centro-Oeste de 7,70\% para 6,46\%. Em consequência, as demais unidades da federação, excetuando-se o Distrito Federal, que manteve 100\% de cobertura, e Goiás, que aumentou o nível de cobertura, viram diminuído o número de municípios que contavam com agências bancárias (1999, p.201).

A liquidação ou privatização dos bancos pú-

\section{A modernização da economia baiana no perí- odo de transição para um projeto modernizador (anos 40-50)}

A economia baiana, na primeira década do século XXI, tem seus principais marcos definidos desde o processo de crise da economia de base agro-exportadora dos anos 1940-50. Em seguida, apresentamos algumas características da dinâmica da economia regional dessa essa época.

No início dos anos 1950, a Bahia apresenta estrutura industrial pouco diversificada, concentrada na produção voltada para o consumo improdutivo, que agregava $81 \%$ do seu valor total. Até então, o setor industrial baiano era pouco representativo na composição do produto interno, representando apenas 6,5\% desse agregado em 1947 (Bahia, 1983). Destaca-se, principalmente, a produção de alimentos, têxteis e derivados do fumo, os quais, individualmente, detinham participação relativa no valor da produção de 50,20\%, 13,50\% e 8,00\%, respectivamente. A participação da produção de meios de produção no total do valor produzido é de aproximadamente $18 \%$ do total, composta, sobretudo, pela transformação de minerais não metálicos, óleos vegetais e alguma produção de produtos metalúrgicos (FIBGE, 1950). É estreita, até então, a vinculação entre a indústria e a agricultura local.

Espacialmente, a produção da cana-de-açúcar e do fumo estava concentrada no Recôncavo, enquanto a do cacau florescia no sul do estado, no espaço configurado como a "região cacaueira”, comandada pelas cidades de Itabuna e Ilhéus. Os excedentes gerados pela cultura do cacau não foram canalizados para outros ramos produtivos nos marcos da região. Segundo Santos (1954), o excedente gerado pela cacauicultura, em grande parte, era deslocado para praças fora da região, em especial, a do Rio de Janeiro.

A produção industrial, por sua vez, concentrava-se em Salvador e em cidades do seu entorno. Nessa época, eram muito débeis os vínculos econômicos intrarregionais. A produção cacaueira, então o setor mais dinâmico da agricul- 
tura baiana, escoava grande parte da produção pelo porto de Ilhéus. Salvador, para além dos vínculos estabelecidos a partir das suas funções políticoadministrativas, também não estabeleceu fortes laços econômicos com os espaços mais distantes da capital. Em grande medida, mantinha ligações estreitas com o comércio de grande distância, seja na exportação de commodities agrícolas, seja a partir do comércio de importação.

$A$ vasta parte do território baiano às margens do Rio São Francisco - o grande sertão do São Francisco - tinha a sua economia articulada com base na agricultura de subsistência, interligada pela navegação no próprio rio e nos seus afluentes, compondo um circuito de comércio regional, e pela pecuária, que abastecia parte do mercado consumidor do estado. A extensa área do semiárido caracterizava-se também pela produção agropecuária de subsistência.

A inserção da Bahia no cenário nacional, na década de 1940, no entanto, sofre uma inflexão, com a perda de posição relativa da economia baiana, determinada pelo esgotamento do padrão de acumulação de capitais agroexportadores que até então lastreavam nacionalmente a sua economia. Já sem a proteção das barreiras fiscais, que protegiam a sua indústria, e impedida de legislar sobre o seu comércio externo, vê aprofundar o fosso que se abrira entre a dinâmica local baiana e a economia nacional.

\section{A exploração e o refino do petróleo e seus efeitos na conformação do projeto de indus- trialização da economia baiana (anos 60-70)}

Os primeiros sinais de mudança nesse quadro resultaram da emergência, em âmbito nacional, do projeto que visava à montagem das bases para o aprofundamento do processo de industrialização, quando a necessidade de exploração de certos recursos naturais implicou a instalação de plantas produtivas fora do eixo Rio-São Paulo. A Bahia, nesse contexto, recebe dois grandes investimentos estatais: a Hidroelétrica do São Francisco, concluída em 1953, e a instalação da Petrobrás, em 1954.
A exploração e a posterior instalação de planta para o refino do petróleo no Recôncavo baiano e em áreas delimitadas mais ao norte repercutiram na estruturação da economia urbana do Recôncavo e de Salvador nos anos correspondentes às décadas de 1950 e 1960, seja pela centralização da política de compra da empresa, em Salvador, seja na construção de estradas e incremento na massa salarial, com repercussões no padrão de consumo (Ritz, 1972). Os efeitos desse empreendimento, no entanto, não foram além dos limites da hoje Região Metropolitana de Salvador. Ritz considera que, a partir de meados dos anos 60 , a política de compras da empresa é reorientada de Salvador para a Região Sudeste, assim como se reduzem também os investimentos em construção da rede viária no estado.

Os efeitos da presença da atividade petrolífera sobre a economia baiana permitem a interpretação apresentada pela missão técnica do Banco Interamericano de Desenvolvimento - BID, que, no início da década de 1970, diagnosticou: "na realidade, a atividade petrolífera se desenvolve em forma quase autárquica e com limitada integração com o resto da economia do estado" (BID, apud Azevedo, 2000, p. 53). Se essa constatação é verdadeira, não se pode desconsiderar o papel que a atividade petroleira tem sobre a estruturação industrial da região, sendo possível afirmar que o petróleo deixa a sua marca na definição do perfil que a indústria baiana passa exibir a partir desde então (Kraychete, 1988). É relevante também o impacto dessa atividade na economia urbana do Recôncavo.

Ao lado do aprofundamento da atividade petrolífera propriamente dita, com a instalação da Refinaria Landulfo Alves, inicia-se, no começo dos anos 1960, as primeiras plantas industriais derivadas do petróleo. Em 1961, a Petrobras resolve instalar uma fábrica de asfalto na ilha de Madre de Deus, para atender ao mercado da Bahia, de Sergipe e Alagoas (Ritz, 1972). No ano seguinte, é inaugurada uma planta de gás natural, cujo objetivo é captar e processar o gás oriundo dos poços petrolíferos. A instalação da planta de gás natural vai 
permitir o surgimento de uma fábrica de amônia, o que vai conformar o Conjunto Petroquímico da Bahia (COPEB), posteriormente integrado ao Complexo Petroquímico de Camaçari (COPEC).

\section{Da especialização da indústria baiana com base no ramo petrolífero à diversificação $a$ partir da "guerra fiscal"}

Para além do ramo petrolífero, o efeito da descoberta e do posterior processamento do petróleo na Bahia se fez mais efetivo a partir da década de 1970, quando são implantadas as plantas petroquímicas. A instalação do Polo Petroquímico de Camaçari repercute no perfil industrial local, acentuando os contornos da sua especialização, processo em curso desde os anos 50. Em 1980, os ramos petrolífero e petroquímico, conjuntamente, vão agregar 51,48\% do valor da produção industrial no estado (FIBGE, 1980).

Os investimentos realizados pela Petrobras não tiveram seus efeitos limitados ao desenvolvimento da química do petróleo. Os serviços ligados à infraestrutura de transporte e armazenamento especializado, entre outros, exigem um segmento da indústria metal-mecânica, o atendimento de obras de caldeiraria, estruturas metálicas industriais e embalagens metálicas, que vieram favorecer o surgimento e desenvolvimento desse segmento industrial especializado. A demanda corrente de materiais de reposição ativa um segmento específico da indústria mecânica (Sampaio, 1974).

No início dos anos 70, já como parte dos estudos que visavam à implantação do Polo Petroquímico, foram detectadas 24 empresas cujas linhas de produção e níveis tecnológicos as indicavam como capacitadas a suprir a demanda das unidades químicas em implantação. Um terço do total das empresas pesquisadas declarou já ser fornecedora da Petrobras (CLAN, 1973). No início dos anos 1980, três décadas após a instalação da atividade de exploração do petróleo, no perfil da indústria instalada no estado, são nítidas as marcas do petróleo na conformação da estrutura que a indústria assume na Bahia.
No início dos anos setenta, verifica-se a ampliação do Centro Industrial de Aratu, implantado em 1967, no município de Simões Filho, vizinho a Salvador, e do Centro Industrial de Subaé, em Feira de Santana, segunda maior cidade do estado e distante cerca de $100 \mathrm{~km}$ da capital. Ambos os centros foram concebidos para acolher empresas industriais de transformação final, que viessem a estabelecer vínculos com o setor produtor de bens intermediários, e eram constituídos por empresas atraídas pelos incentivos fiscais patrocinados pela Superintendência de Desenvolvimento do Nordeste (SUDENE) e pelo Banco do Nordeste, aos quais foram acrescidos incentivos patrocinados pelo governo estadual.

As mudanças na condução da economia nacional - que levaram, a partir da década de 1980, a mudanças no papel do Estado na condução da economia - resultaram na fuga de empresas atraídas por tais incentivos, o que contribuiu para que a matriz industrial baiana não se completasse, tal como havia sido idealizada pelo planejamento estatal. Tal fato só ressalta o caráter complementar que a indústria baiana guarda com a indústria sediada na Região Sudeste. Ainda hoje, a matriz industrial baiana carece da sua seção de produção de bens de capital e bens de consumo.

Merece ser destacado, ainda, o impulso dos investimentos na indústria no ramo da construção civil, seja a construção civil pesada, seja a voltada para a construção de habitação ou infraestrutura, tais como abertura de novas avenidas, construção de rede de saneamento e abastecimento de água, entre o final de 1960 até a década de 1980.

As mudanças ocorridas no perfil da indústria na Bahia, desde a implantação da atividade petroleira, passando pela instalação do CIA até o COPEC, fazem com que a participação da indústria no PIB estadual evolua de 12,00\%, em 1960, para $21,2 \%$, em 1980. Verifica-se, nesse ano, o primeiro registro no qual a atividade industrial toma o primeiro lugar na composição desse agregado, ocupado antes pelo comércio ou pela agricultura.

Nesse período, a implantação e o desenvolvimento de uma nova zona industrial na Bahia, embo- 
ra sejam fatos significativos, quando comparados com o estágio anterior e o ocorrido nos demais estados nordestinos, ficaram concentrados na Região Metropolitana de Salvador. Tal fato veio a fortalecer desequilíbrios intrarregionais já marcantes na formação econômica e social da Bahia. A urbanização do espaço que hoje compreende a Região Metropolitana de Salvador, a partir da década de 1950, ganhou nova dinâmica. Os investimentos aqui realizados, em boa parte, foram liderados ou contaram com apoio decisivo do Estado, em sua instância federal ou estadual, seja como produtor direto, seja atendendo às demandas de infraestrutura industrial e urbana, serviços especializados e de crédito, entre outras. O Estado da Bahia passa, nesse momento, por reforma do seu aparelho administrativo, e recebe também representação de agências federais, o que impulsiona a modernização do setor de serviços.

A população da Região Metropolitana de Salvador, em 1980, atinge 1,8 milhões de habitantes, 1,5 milhões só na capital. Nessa época, apenas oito centros urbanos baianos contavam com população superior a 60 mil habitantes e, desses, apenas três ultrapassavam a marca dos $100 \mathrm{mil}$ habitantes. Entre eles, encontra-se Feira de Santana, destacada, desde a conclusão da rodovia que liga a Bahia ao Rio de Janeiro em 1963, como o principal entroncamento rodoviário de ligação entre as regiões Sudeste e Nordeste. Vitória da Conquista, outra cidade situada às margens da mesma Rio-Bahia, também registra crescimento da sua população e passa a figurar entre as maiores no estado.

A Bahia registrou, nesse momento, o crescimento de algumas cidades situadas às margens das principais rodovias de ligação entre o Sudeste e o Nordeste - BR 161 e BR 101 - o que, numa direção, facilitava o transporte de bens intermediários e mão-de-obra para alimentar a indústria implantada no Sudeste e, em outra, trazia os bens de consumo final para o mercado consumidor nordestino (Porto, 2002).

Na passagem da década dos anos 1970 para os de 1980, as manifestações da crise - que atingira mais fortemente, até então, os países desenvolvidos - chegam aos países da periferia. Os indica- dores de desempenho da economia brasileira passam a apresentar sinais de desaceleração econômica, com reflexos diretos sobre os setores mais dinâmicos da indústria baiana: o PIB baiano, que havia crescido, entre 1975 e 1980, em média, 8,8\% ao ano, no decorrer dos anos 80 e 90 cresceu 2,4\% e 2,5\% anuais, respectivamente. ${ }^{3} \mathrm{O}$ desempenho da indústria instalada na Bahia, em grande medida, dada a sua relação complementar, dependia do verificado na Região Sudoeste.

Nos anos 90 - já desmontado o sistema de planejamento que havia orientado os capitais no período anteriores-, modificações ocorridas na produção enagestãoa partir da introdução das novas tecnologias, assim como o barateamento das telecomunicações e do transporte, entre outras, repercutiram na economia baiana, possibilitando relocalização de empresas ou a atração de novas unidades produtivas que se deslocaram em busca de redução dos custos salariais e de benefícios fiscais concedidos a partir de competição fiscal, a chamada "guerra fiscal". Constituem os exemplos mais citados de atração de empresas, segundo esse procedimento, a planta da Ford, em Camaçari, e de empresas de calçados, atraídas do Rio Grande do Sul e São Paulo, e implantadas de forma dispersa, em cidades do interior do estado. Essa política também atraiu empresas em ramos diversificados, como a de produção de defensivos agrícolas (projeto da Monsanto, em Camaçari), montagem eletrônica (polo de informática), em Ilhéus, e outras de menor magnitude. A implantação de call-centers de telemarketing também compõe o quadro de atração de novas empresas e atividades a partir das vantagens expressas nos custo da mão-de-obra.

\section{A modernização da economia agrária e os im- pactos socioespaciais na implementação dos serviços}

A partir do final da década de 1970, verifica-se a expansão do setor agrário baiano, seja com a modernização agrícola propriamente dita, seja com encadeamentos agroindustriais. Em especial, ${ }^{3}$ www.sei.ba.gov.br 
as fronteiriças regiões do Extremo Oeste, do Baixo Médio São Francisco e do Extremo Sul destacamse entre os espaços onde tal modernização resultou em significativas mudanças socioeconômicas.

O Vale do São Francisco passou, nas últimas décadas, por importantes modificações, iniciadas com a implantação dos projetos públicos de irrigação e a introdução da fruticultura ao longo das margens do Rio São Francisco, que modificaram os processos produtivos regionais. Como partes dessa dinâmica, cidades como Juazeiro e de Bom Jesus da Lapa passam a receber montantes significativos de investimentos, conseguindo atrair grande número de grupos econômicos para a produção irrigada e o aproveitamento agroindustrial. Na esteira de tais investimentos, essas duas cidades absorvem representações de instituições federais que administram o uso das águas, seja para a produção de energia, seja para a utilização na irrigação da agricultura, como também concentram filiais de casas comerciais de venda de produtos destinados à agricultura, assim como serviços de natureza diversa.

O Extremo Oeste é parte do território baiano integrado à dinâmica da ocupação dos cerrados brasileiros, espaço articulado a partir da expansão da cultura da soja e da fruticultura, no final dos anos 70 e início dos 80 do século passado. Desde a implantação do Programa de Ocupação Econômica do Oeste pelo governo estadual, a região recebe investimentos que visam à melhoria da infraestrutura, tornando-se espaço promissor para investimentos no agronegócio.

A partir da década de 1990, a microrregião do Extremo Sul da Bahia, cujas vantagens naturais permitem maior produtividade, quando comparadas com tradicionais zonas produtoras, também atraiu grandes empresas - Bahia Sul Celulose em Mucuri, Aracruz Celulose em Nova Viçosa e Veracel Celulose em Eunapólis - investimentos voltados para a produção de celulose.

A oligopolização que passa a se verificar no espaço agrícola tem promovido impactos socioespaciais que ultrapassam as atividades agrícolas propriamente ditas, criando ou desenvolvendo um novo sistema urbano mais complexo para atender às demandas advindas do agronegócio, da agricultura modernizada e da agroindustrialização. A urbanização derivada do agronegócio tem dinamizado um setor terciário composto por empresas agropecuárias, fornecedores de insumos químicos e implementos mecânicos, prestadores de serviços, laboratórios, cadeias de supermercados e lojas de varejo de bens de consumo duráveis, lojas de distribuição comercial, empresas de marketing e bancos, entre outros serviços.

\section{A PRESENÇA DOS BANCOS NO DESENVOL- VIMENTO BAIANO RECENTE}

A trajetória recente da economia baiana contou com forte aporte de créditos e incentivos fiscais e financeiros. Os bancos cumpriram papel relevante nesse processo, tanto os públicos, criados para dar suporte aos processos desenvolvimentistas, como os privados, de implantação nacional e (ou) regional.

A começar pelos bancos cujos capitais têm origem regional, a Bahia contou com dois bancos privados: o Banco da Bahia, adquirido no decorrer dos anos 70 pelo Banco Brasileiro de Descontos (BRADESCO), e o Banco Econômico da Bahia, absorvido pelo Excel, no bojo da reestruturação bancária dos anos 1990. Em 1990, o Econômico mantinha 36,51\% dos depósitos e 69,12\% dos créditos concedidos concentrados na Bahia (Amado, 2006). Os dois bancos baianos têm suas origens associadas aos interesses da burguesia mercantilfinanceira ligada ao comércio de exportação e de importação.

Por outro lado, bancos privados de grande porte, que operam em âmbito nacional, também se fazem presentes na Bahia, a partir dos anos 70. O BRADESCO, fruto da compra do Banco da Bahia e do BANEB, passa a ser o maior banco privado na rede de agências implantadas na Bahia. No entanto, em 1990, apenas 0,14\% do total de empréstimos e $3,20 \%$ do total da carteira de créditos, respectivamente, estavam na Bahia (Amado, 2006).

Uma rede de bancos já se fazia presente no estado da Bahia, com vistas a dar suporte ao pro- 
cesso de desenvolvimento: o Banco Nacional de Desenvolvimento Social (BNDES), o Banco Nacional de Habitação (BNH), que operavam apoiados, prioritariamente, na rede pública estadual, o Banco Nacional de Desenvolvimento do Nordeste (BNB), com atuação a partir de sua própria rede, e ainda os bancos de capital público, o Banco do Brasil, tradicional fornecedor de crédito agrícola, e a Caixa Econômica Federal, que mantinham agências no estado. Além desses, a Bahia contava ainda com mais dois bancos públicos: o Banco do Estado da Bahia (BANEB), criado em 1966, ${ }^{4}$ e o Banco de Desenvolvimento do Estado da Bahia (DESENBANCO), criado em 1966, ${ }^{5}$ ambas instituições fundadas nos marcos da Reforma Bancária e Financeira de 1964-1965.

\section{Papel e estruturação do BANEB no contexto de evolução da economia baiana}

O BANEB, definido como banco misto, embora sua natureza comercial fosse mais notória, era também um banco de corte desenvolvimentista, enquanto o DESENBANCO assume o caráter estrito de banco de desenvolvimento.

Segundo periodização proposta por Lima (2001), a trajetória do BANEB intercala momentos de dificuldades. Tais dificuldades resultavam, principalmente, tanto de questões de natureza administrativa, relacionadas com o governo estadual, mas que transbordavam para o desempenho financeiro, como também aquelas decorrentes da presença marcante na articulação com instituições nacionais e internacionais, na captação de recursos e no financiamento a empreendimentos associados à expansão da economia baiana, que passa a demandar serviços financeiros adequados. ${ }^{6}$

${ }^{4}$ O Banco do Estado da Bahia tem a sua origem ligada ao Banco de Fomento do Estado da Bahia (BANFEB), criado em 1955, no governo de Régis Pacheco, embora, de fato, a instituição só venha a funcionar cinco anos depois, já no segundo governo de Juracy Magalhães.

${ }^{5}$ O Banco de Desenvolvimento do Estado da Bahia, por sua vez, originou-se do Fundo de Desenvolvimento Agroindustrial (FUNDAGRO).

${ }^{6}$ A parte que segue, sobre a atuação do Banco do Estado da Bahia, baseia-se no trabalho de Lima (2001).
Os momentos de maior expansão da história do BANEB centram-se nos períodos de 1967 a 1974 e de 1979 até 1982 . O desempenho registrado no primeiro período está associado à dinâmica da economia nacional, assim como da economia baiana, quando essa última ampliava o seu parque industrial, como já observado. Nesse período, o crescimento da economia baiana aproximou-se das tendências apontadas em termos da economia nacional. Para tal desempenho contribuíram, de maneira significativa, os investimentos realizados com apoio da Superintendência de Desenvolvimento do Nordeste (SUDENE). No exercício relativo a 1969, mais de dois terços dos projetos analisados por essa instituição correspondem a investimentos a serem realizados na Bahia, com índice de aprovação de 37\% do total aplicado pela SUDENE.

Esse momento é marcado também por um grande esforço do governo baiano em promover as exportações, conseguindo, em 1974, ampliar as vendas para o exterior em $116 \%$, elevando a participação das exportações da Bahia, no conjunto nacional, de 4,70\%, em 1973, para 8,00\%, em 1974.

Portanto, o desempenho do BANEB, na passagem dos anos 70 para os 80, resulta mais de uma dinâmica econômica do próprio estado. Tal desempenho, nesse período, também é reflexo da crescente captação de recursos externos, que, entre 1981 e 1982, cresceu a partir dos dispositivos da Resolução 63. Tal movimento, consoante com o papel atribuído aos bancos, particularmente aos bancos públicos - de captadores de recursos externos, visando ao equilíbrio do balanço de pagamentos -, contribui para a crise de liquidez que o banco vai enfrentar após o período de crescimento acelerado.

A importância do BANEB como agente financeiro no cenário baiano pode ser ressaltada pela distribuição da sua rede de agências, o que proporcionou a interiorização da atividade financeira no estado (Quadro 1). Na sua criação, o BANEB já herda uma pequena rede de agências mantidas pela instituição que lhe dá origem. O quadro a seguir apresenta a evolução da sua rede de agências em municípios baianos, entre 1964 e 1975.

O momento de maior ampliação da rede do 
Quadro 1 - Municípios com presença de agências do BANEB entre 1964 e 1975

\begin{tabular}{|c|l|}
\hline Ano & \multicolumn{1}{|c|}{ Município } \\
\hline 1964 & Bom Jesus da Lapa, Itiruçu, Itororó e Ubaíra \\
\hline 1965 & Carinhanha, Euclides da Cunha, Itaberaba, Maragogipe e Itagi \\
\hline 1966 & Salvador (agências da Calçada e Av. 7 de Setembro), Alagoinhas, Camacã e Santana \\
\hline 1967 & Itapetinga e Salvador (agência Baixa dos Sapateiros) \\
\hline $1969^{*}$ & Salvador (agência Campo Grande), Camamu, Itanhém e Guanambi \\
\hline 1972 & Teixeira de Freitas \\
\hline 1973 & Salvador (agência CEASA) e Catu \\
\hline 1974 & Encruzilhada, Ibirapitanga, Jeremoabo, Santa Inês, Uruçuca e Queimadas \\
\hline 1975 & $\begin{array}{l}\text { Brotas de Macaúbas, Condeúba, Cotegipe, Floresta Azul, Mucuri, Riachão do Jacuípe, Rio Real, Una, Camaçari } \\
\text { (Complexo Petroquímico) e Sobradinho/Juazeiro (Barragem de Sobradinho) }\end{array}$ \\
\hline
\end{tabular}

Fonte: Elaboração da autora com base em Lima (2001).

* Em 1969, o BANEB incorpora seis agências do Banco Auxiliar de São Paulo: Boquira, Amélia Rodrigues, Jacobina, Pojuca, São Francisco do Conde e Santo Estêvão.

BANEB, no entanto, ocorre entre 1979 e 1982. Nesse período foram instaladas cento e trinta e três novas agências, vinte e cinco postos especiais de prestação de serviços e nove lojas de poupança. No início dos anos oitenta, mais da metade dos municípios baianos contavam com agências desse banco.

Além da ampliação do número de agências, em consonância com as diretrizes do governo estadual, o BANEB promove a formação de um conglomerado financeiro mais complexo, cuja liderança cabia ao próprio banco. Assim, no final de 1982, o Grupo BANEB apresentava a seguinte composição: Banco do Estado da Bahia (principal empresa do conglomerado); BANEB Corretora de Câmbio e Valores Imobiliários; BANEB Crédito Imobiliário; BANEB Distribuidora de Títulos e Valores Mobiliários da Bahia; BANEB Financeira - Créditos, Financiamento e Investimento; BANEB Corretora de Seguros.

A ampliação da rede de agências e a formação do conglomerado do BANEB atendem tanto a interesses do governo baiano como guardam sintonia com a estratégia do Banco Central, dirigida a estender a assistência bancária a todos os municípios, melhorar a prestação de serviços bancários, disponibilizar assistência bancária a municípios menos atendidos e efetuar medidas de regionalização bancária.

Com a ampliação de atribuições e de expansão da rede, o BANEB se constitui, nesses anos, em importante suporte à acumulação de capital no es- tado, apoiando investimentos públicos e privados destinados, em especial, à expansão da infraestrutura, indicação dos programas de desenvolvimento econômico apresentados por sucessivos governos do estado. Destacam-se, na atuação do Banco, os financiamentos orientados para o setor público em obras destinadas à ampliação das vias de transporte, com construção e pavimentação, telefonia, eletrificação e implantação de infraestrutura urbana, com obras de saneamento básico. Para os financiamentos de obras de infraestrutura, foi fundamental a intermediação com o BNH, iniciada em 1969, e que se manteve como importante fonte de recursos até a primeira metade da década de 1980. São citadas como obras relevantes financiadas pelo BANEB: a construção da Barragem de Pedra do Cavalo para o abastecimento de água de Salvador e cidades vizinhas; a construção da rodovia que liga Feira de Santana a Juazeiro; e a construção do Centro Administrativo da Bahia.

Para a viabilização de tais empreendimentos, o BANEB contribuiu não só como financiador direto, mas agiu também na concessão de fianças e garantias para órgãos do Estado e empreiteiras contratadas por ele para aquisição de financiamento em outras instituições.

A Tabela 1, a seguir, apresenta a distribuição percentual da carteira de créditos do BANEB, entre 1964 e 1986, segundo classificação apresentada em seus relatórios anuais. 
Elsa Sousa Kraychete

Tabela 1 - Distribuição da carteira de créditos do BANEB entre 1964 e 1986

\begin{tabular}{|c|c|c|c|c|c|c|c|}
\hline Ano & Crédito Geral & Agropecuária & Indústria & Comércio & Setor Público & Habitação & Outros \\
\hline 1964 & - & 52,00 & 16,00 & 28,00 & 4,00 & - & - \\
\hline 1965 & - & 34,00 & 21,00 & 18,00 & 27,00 & - & - \\
\hline 1966 & - & 30,00 & 17,00 & 13,00 & 40,00 & - & - \\
\hline 1967 & - & 27,00 & 15,00 & 12,00 & 42,00 & - & 4,00 \\
\hline 1968 & - & 16,00 & 10,00 & 10,00 & 59,00 & - & 5,00 \\
\hline 1969 & - & 11,00 & 9,00 & 12,00 & 61,00 & - & 7,00 \\
\hline 1970 & - & 12,00 & 9,00 & 9,00 & 65,00 & - & 5,00 \\
\hline 1971 & - & n.d & n.d & n.d & 53,00 & - & n.d \\
\hline 1972 & - & n.d & n.d & n.d & 42,00 & - & n.d \\
\hline 1973 & - & n.d & n.d & n.d & 36,00 & - & n.d \\
\hline 1974 & - & n.d & n.d & n.d & 28,00 & - & n.d \\
\hline 1975 & 58,00 & 6,00 & - & - & 32,00 & 4,00 & - \\
\hline 1976 & 35,00 & 6,00 & - & - & 48,00 & 11,00 & - \\
\hline 1977 & 32,00 & 6,00 & - & - & 44,00 & 19,00 & - \\
\hline 1978 & 29,00 & 5,00 & - & - & 47,00 & 19,00 & - \\
\hline 1979 & 29,00 & 8,00 & - & - & 40,00 & - & 23,00 \\
\hline 1980 & 23,00 & 11,00 & - & - & 43,00 & - & 23,00 \\
\hline 1981 & 20,00 & 10,00 & - & - & 54,00 & - & 16,00 \\
\hline 1982 & 14,00 & 8,00 & - & - & 59,00 & - & 19,00 \\
\hline 1983 & 9,00 & 10,00 & - & - & 60,00 & - & 21,00 \\
\hline 1984 & 11,00 & 5,00 & - & - & 66,00 & - & 18,00 \\
\hline 1985 & 11,00 & 5,00 & - & - & 72,00 & - & 12,00 \\
\hline 1986 & - & 10,00 & - & - & 61,00 & - & 29,00 \\
\hline
\end{tabular}

Fonte: Elaboração da autora, a partir dos dados de Lima (2001).

A partir do início dos anos 90, o BANEB mentos os repasses oriundos do BNDES, FINAME passa por sucessivos períodos de falta de liquidez, e BNH, fundos estaduais, depósitos do Imposto o que justifica a sua privatização, já num contexto sobre Circulação de Mercadorias (ICM) e recursos de redefinição do papel do estado na economia próprios, a marca do DESENBANCO se fez prenacional, submetida aos ajustes institucionais e sente no financiamento aos setores público e prireforma do Estado. Assim, em julho de 1999, foi vado. No período entre 1966 e 2001, os desembolconcluído o processo de privatização do banco, sos acumulados atingiram R $\$ 12,7$ bilhões, em quando o seu controle acionário e administrativo valores de dezembro de 2001. Quando se observa passou às mãos do Banco Brasileiro de Descontos. o comportamento dos desembolsos, verifica-se que, durante os dezesseis primeiros anos de existência da instituição, houve um crescimento constante,

\section{A constituição do Banco de Desenvolvimento do Estado da Bahia no financiamento dos se- tores público e privado}

O Banco de Desenvolvimento do Estado da Bahia (DESENBANCO) ${ }^{7}$ também foi importante agente financiador da acumulação de capitais na Bahia a partir de meado dos anos 1960. Tendo como principais fontes de recursos para financia-

7 Os dados e as informações relativos à atuação do DESENBANCO têm por base o trabalho Cavalcanti (2004). até atingir, em 1982, o pico de liberação anual de R\$ 900 milhões, em valores de dezembro de 2001. O segmento privado foi atendido, prioritariamente, em seu setor industrial. São frequentemente citados, nos relatórios da instituição, os financiamentos a empresas instaladas no Centro Industrial de Aratu, Polo Petroquímico de Camaçari (implantação e posterior ampliação, já nos anos 1980) e a alguns distritos industriais instalados em municípios do interior do estado. O Complexo Industrial Ford Nordeste, instalado em 2001, já no período imediatamente anterior à transformação do banco em Agên- 
cia de Fomento, a atual DESENBAHIA, também obteve financiamento dessa fonte.

Em sintonia com as características da indústria implantada no estado, os setores que mais receberam créditos correspondiam a empresas dos ramos químico, petroquímico, de extração mineral, metalúrgico, metal-mecânico e eletro-eletrônico. Em montantes demenor magnitude, aparecem o segmento têxtil e o madeireiro. No que tange à agroindústria, as maiores referências são à concessão de créditos a empresas agroindustriais, no Extremo Oeste e no Baixo Médio São Francisco. Observando os setores industriais contemplados, a maior parte dos financiamentos concentrou-se na RMS.

Em 1985, a rede bancária baiana, segundo Hannequim (1989), contava com 655 agências, o que representava $6 \%$ do total de agências instaladas no país. A participação relativa da Bahia no conjunto nacional também é pouco expressiva quando se observa a captação de depósitos e a concessão de créditos, que se situavam em torno de 3,50\% (1989, p.184).

As 655 agências bancárias autorizadas a operar na Bahia estavam instaladas em 363 praças, significando que mais de 70\% dos municípios baianos eram atendidos por bancos. Embora esse dado revele uma interiorização geográfica da atividade bancária no estado, cerca de $22 \%$ dessas unidades encontravam-se situadas em Salvador. Mais revelador da concentração bancária e financeira na praça de Salvador são os dados relativos às operações de créditos e depósitos, segundo os quais a capital do estado concentrava $90 \%$ e $80 \%$, respectivamente (p.187).

A hierarquização financeira da rede bancária destaca entre as dez principais praças, as cidades indicadas no Quadro 2.

Desse conjunto de praças, apenas cinco mantêm a razão entre crédito e depósito superior a 1, denotando serem praças capazes de atrair créditos: Salvador $(1,86)$; Serrinha $(1,53)$; Camaçari (1,32); Vitória da Conquista $(1,22)$; e Ilhéus $(1,07)$ (Hannequim, 1989, p.200).

Os municípios classificados entre os dez maiores guardam larga distância, sendo a praça de Salvador a primeira colocada. O volume de depó-
Quadro 2 - Bahia: hierarquização financeira das praças bancárias - 1985

\begin{tabular}{|c|c|c|}
\hline & $\begin{array}{c}\text { Principais praças por } \\
\text { captação de depósitos }\end{array}$ & $\begin{array}{c}\text { Principais praças por } \\
\text { concessão de créditos }\end{array}$ \\
\hline $1^{\circ}$ & Salvador & Salvador \\
\hline $2^{\circ}$ & Feira de Santana & Camaçari \\
\hline $3^{\circ}$ & Camaçari & Itabuna \\
\hline $4^{\circ}$ & Itabuna & Vitória da Conquista \\
\hline $5^{\circ}$ & Vitória da Conquista & Feira de Santana \\
\hline $6^{\circ}$ & Ilhéus & Ilhéus \\
\hline $7^{\circ}$ & Juazeiro & Jequié \\
\hline $8^{\circ}$ & Jequié & Juazeiro \\
\hline $9^{\circ}$ & Guanambi & Barreiras \\
\hline $10^{\circ}$ & Barreiras & Serrinha \\
\hline
\end{tabular}

Fonte: Banco Central do Brasil. Elaborado pela autora a partir de Hannequim (1989).

sitos registrado em Feira de Santana, por exemplo, que se situa no $2^{\circ}$ lugar na hierarquia de depósitos, corresponde a 2,25\% do registrado em Salvador. Em relação à hierarquia dos créditos, semelhante é a posição de Camaçari, que detém apenas $2,02 \%$ do volume de créditos registrado na praça na primeira colocação, ou seja, Salvador. As demais praças que se destacam no rankink financeiro do estado correspondem a cidades que funcionam como "capitais regionais" em suas respectivas microrregiões.

\section{AREDE BANCÁRIA NO ESTADO DA BAHIA: estrutura e hierarquização}

A estrutura e a espacialização da rede bancária na Bahia, em 2005, serão apresentadas e analisadas a partir do número de agências autorizadas e dos estoques médios de depósitos e de créditos. Os dados utilizados são do Sistema de Informações do Banco Central (SISBACEN), disponível no portal do Banco Central.

A análise proposta será realizada a partir dos seguintes indicadores:

- Número de agências bancárias por município.

- Indicador de estoque: média do volume de recursos captados e aplicados.

- Indicador de centralidade: posição hierárquica das praças financeiras de acordo com a participação relativa de seus respectivos indicadores de estoques. 
- Indicador de dinamismo financeiro: definido pela razão crédito/depósito X 100 (E/D).

O dinamismo financeiro de cada praça será demonstrado a partir dos resultados encontrados na razão crédito/depósito:

- Praça financeira dinâmica: E/D > 1

- Praça financeira estagnada: $\mathrm{E} / \mathrm{D}=1$

- Praça financeira com pouca vitalidade: $\mathrm{E} / \mathrm{D}<1$

\section{A posição relativa da rede bancária baiana frente às principais praças bancárias brasilei- $\operatorname{ras}(2005)$}

O exame dos dados relativos à atividade financeira na Bahia revela que o governo do estado tem participação modesta no cenário financeiro nacional. Em 2005, a Bahia absorve 4,21 \% do número de agências, $1,57 \%$ do estoque médio de depósitos e 1,92\% do estoque médio de créditos do total brasileiro. Nesse mesmo ano, o estado de São Paulo concentrava 32,31\% do total de agências e mais da metade do estoque médio de depósitos e de créditos. Mesmo quando a Bahia é comparada com os estados de Minas Gerais e Rio de Janeiro, a posição baiana é relativamente inferior, como pode ser observado na Tabela 2 .

Tabela 2 - Bahia: posição relativa no sistema financeiro brasileiro por número de agências, estoque médio de depósitos e estoque médio de créditos - 2005

\begin{tabular}{|c|c|c|c|}
\hline Estado & No Agências & $\begin{array}{l}\text { Estoque Médio } \\
\text { de Depósitos }\end{array}$ & $\begin{array}{l}\text { Estoque Médio } \\
\text { de Créditos }\end{array}$ \\
\hline Bahia & 4,21 & 1,57 & 1,92 \\
\hline Rio de Janeiro & 9,43 & 9,37 & 7,48 \\
\hline Minas Gerais & 10,39 & 5,60 & 6,41 \\
\hline São Paulo & 32,31 & 53,98 & 55,34 \\
\hline Brasil & 100,00 & 100,00 & 100,00 \\
\hline
\end{tabular}

Fonte: Banco Central do Brasil/SISBACEN. Cálculos da autora.

\section{A cobertura do território baiano pela rede ban- cária}

A rede bancária na Bahia, quando observada pela presença ou ausência de agências, caracteriza-se, por um lado, pela alta concentração em algumas praças e, por outro, pelo grande número de municípios que não contam com agências bancárias. Em 2005, a Bahia contava com 739 agências instaladas em 265 praças, que cobriam $63 \%$ do total dos municípios baianos, enquanto 37\% (152 municípios) não contavam com a presença de ban$\cos ^{8}{ }^{8}$ Tal situação reflete a concentração das atividades econômicas, resultante da distribuição heterogênea da sua indústria, da agricultura moderna e da oferta de serviços em espaços delimitados do território baiano e da rede urbana correspondente. A distribuição das agências bancárias nas praças baianas, como se verá, guarda correspondência com essa realidade. Aos municípios sem agências correspondem 5,11\% do total do PIB, enquanto as praças que contam com mais de 10 agências respondem por 45,24\% desse agregado. É também significativo o número de municípios que conta apenas com uma só agência. Nessa situação encontram-se 173 municípios, o que corresponde a $65 \%$ do total (Tabela 3).

Em posição oposta, apenas seis municípios contam com mais de dez agências, cobrindo $45,24 \%$ do PIB. Nesse conjunto, sobressai a posição ocupada por Salvador, que, com 215 estabelecimentos bancários, responde, aproximadamente, por $25 \%$ do total de agências. A distância dessa praça em relação às demais é considerável: Feira de Santana, a segunda colocada, contava com 26 agências; Itabuna 13 agências; Vitória da Conquista e Camaçari 12 agências; e Lauro de Freitas 11 agências. A esse conjunto correspondem 45,24\% do PIB baiano.

É também significativo o número de municípios que contam apenas com duas agências - em geral, uma agência do Banco do Brasil e uma agência do Bradesco -, os quais representam $15 \%$ do total. A produ-

${ }^{8} \mathrm{O}$ fato de o município não contar com agência bancária instalada não significa que esteja sem acesso a determinados serviços financeiros, como recebimento de contas e de títulos de tributos, pagamento de salários e benefícios, abertura de contas, acesso a saldos e extratos, realização de depósitos, abertura de contas, saques e transferências e mesmo recepção e encaminhamento de pedidos de crédito. A parceria entre bancos e empresas de outra natureza, como a realizada entre o BRADESCO e a Empresa Brasileira de Correios e a da Caixa Econômica e as casas lotéricas, por exemplo, leva vários dos serviços bancários às praças desassistidas pela rede convencional de agências. 
Tabela 3 - Bahia: distribuição de agências por municípios e representação no PIB - 2005

\begin{tabular}{l|c|c|c}
\hline \multirow{2}{*}{$\begin{array}{c}\mathbf{N}^{\circ} \text { de } \\
\text { agências }\end{array}$} & \multicolumn{3}{|c}{$\mathbf{2 0 0 5}$} \\
\cline { 2 - 4 } & $\mathbf{N}^{\circ}$ Município & \% & \% PIB \\
\hline 1 & 173 & 65,28 & 11,56 \\
\hline 2 & 40 & 15,09 & 13,70 \\
\hline 3 a 10 & 46 & 17,36 & 24,39 \\
\hline$>10$ & 6 & 2,26 & 45,24 \\
\hline Total & 265 & 100,00 & 94,89
\end{tabular}

Fonte: Banco Central do Brasil/SISBACEN e Superintendência de Estudos Econômicos e Sociais da Bahia. Cálculos da autora.

ção correspondente a tais municípios corresponde a 13,70\% do PIB baiano. A concentração produtiva no espaço baiano é reveladora de um processo de regionalização heterogêneo e desigual, que, do ponto de vista da urbanização, não se constituiu numa extensa rede de cidades de porte médio com oferta de serviços, inclusive financeiros, modernos e de qualidade. Assim, apenas $17 \%$ das cidades baianas que contam com agências bancárias têm entre três e dez agências.

A concentração das agências em áreas específicas do estado também fica patente quando se tomam as mesorregiões como espaço de observação: a Região Metropolitana de Salvador concentra 39,70\% das agências, seguida pelas mesorregiões Centro Sul, Sul e Centro Norte, com 15,80\%, $14,60 \%$ e 13,00\%, respectivamente. Em seguida, aparecem as mesorregiões Nordeste com 7,20\%, Vale

\section{A distribuição dos bancos públicos e privados por mesorregiões}

O exame relativo à distribuição das agências sob o critério da propriedade do capital nas mesorregiões confirma a estratégia de os bancos privados ocuparem as praças comprovadamente mais rentáveis e já consolidadas, enquanto os bancos controlados pelo capital público, aderentes às políticas governamentais, fazem-se mais presentes nas regiões pioneiras e nas regiões onde se verificam dinâmicas econômicas mais deprimidas.

A distribuição da rede bancária por propriedade do capital revela a importância da presença dos bancos de capital público que, para o conjunto do estado, participam com $52,77 \%$ do total, correspondendo a 390 agências de bancos públicos e 349 agências de bancos privados. Só o Banco do Brasil, com 275 agências, corresponde a $37,21 \%$ do total de agências em funcionamento da Bahia.

Na distribuição por mesorregião - à exceção da Região Metropolitana de Salvador, onde os bancos privados detêm 59,32\% do total de agências -, predominam as agências de bancos controlados por capitais públicos. Na Região Oeste, os bancos controlados por capitais públicos chegam a representar $70 \%$ do total de agências implantadas (Tabela 4).

\section{Vitalidade financeira, distribuição dos esto- ques de depósito e crédito por mesorregiões}

A movimentação financeira realizada pelos bancos, na Bahia, em 2005, registra estoque médio mensal de depósitos de $\mathrm{R} \$ 13.498 .738 .030,75$ e estoque médio mensal de créditos de $\mathrm{R} \$$ 9.844.350.010,17 (idem). A razão crédito/depósito foi da ordem de $0,73 \%$, denotando que a economia do estado, em meados dos anos 2000, apresentou pouca capacidade de atrair capitais na forma de créditos (Tabela 5).

A distribuição espacial das transações financeiras concentra-se na Região Metropolitana de Salvador, a grande distância das demais mesorregiões, tanto no que se refere às transações referentes a depósitos como àquelas relativas a créditos. Essa mesorregião, que concentra 55,30\% do PIB, aparece como responsável por $65,50 \%$ do total de depósitos e por $59,40 \%$ dos créditos efetuados no estado. Na dinâmica interna da microrregião comandada por Salvador, ${ }^{9}$ ela absorve $94 \%$ e $96 \%$ do estoque médio de depósito e do estoque médio de créditos, respectivamente, des-

\footnotetext{
Compõem a Microrregião de Salvador os municípios de Camacari, Candeias, Madre de Deus, São Francisco do Conde, Simões Filho (municípios onde se concentra a maior parte da indústria baiana), Dias D’Ávila, Itaparica, Lauro de Freitas e Vera Cruz.
} 
Tabela 4 - Bahia: distribuição da rede bancária por mesorregião e propriedade do capital - 2005

\begin{tabular}{|c|c|c|c|c|c|c|c|c|c|c|c|c|c|c|c|c|c|c|}
\hline \multirow{3}{*}{$\begin{array}{l}\text { Estado/ } \\
\text { Mesorregião }\end{array}$} & \multirow{3}{*}{$\begin{array}{c}\text { Total } \\
\text { (a) }\end{array}$} & \multirow{3}{*}{$\%$} & \multicolumn{8}{|c|}{ Banco Público } & \multicolumn{6}{|c|}{ Banco Privado } & \multirow{3}{*}{$\begin{array}{c}(\mathbf{a} / \mathbf{b}) \\
\mathbf{X} \\
\mathbf{1 0 0}\end{array}$} & \multirow{3}{*}{$\begin{array}{c}\text { (c/a) } \\
\mathbf{X} \\
\mathbf{1 0 0}\end{array}$} \\
\hline & & & \multirow{2}{*}{$\begin{array}{c}\text { Total } \\
\text { Abs (b) }\end{array}$} & \multirow{2}{*}{$\%$} & \multicolumn{2}{|c|}{ BB } & \multicolumn{2}{|c|}{ CEF } & \multicolumn{2}{|c|}{ BF } & \multirow{2}{*}{$\begin{array}{c}\text { Abs } \\
\text { (c) }\end{array}$} & \multirow{2}{*}{$\%$} & \multicolumn{2}{|c|}{ Multiplo } & \multicolumn{2}{|c|}{ Comercial } & & \\
\hline & & & & & Abs & $\%$ & Abs & $\%$ & Abs & $\%$ & & & Abs & $\%$ & Abs & $\%$ & & \\
\hline BAHIA & 739 & 100,00 & 390 & 100,00 & 275 & 100,00 & 80 & 100,00 & 35 & 100,00 & 349 & 100,00 & 348 & 100,00 & 1 & 100,00 & 53,00 & 47,00 \\
\hline Oeste & 30 & 4,00 & 21 & 5,00 & 16 & 6,00 & 1 & 1,00 & 4 & 11,00 & 9 & 3,00 & 9 & 3,00 & 0 & 0,00 & 70,00 & 30,00 \\
\hline V. Sanfranciscano & 41 & 5,00 & 24 & 6,00 & 17 & 6,00 & 4 & 5,00 & 3 & 9,00 & 17 & 5,00 & 17 & 5,00 & 0 & 0,00 & 59,00 & 42,00 \\
\hline Centro Norte & 96 & 13,00 & 61 & 16,00 & 45 & 16,00 & 9 & 11,00 & 7 & 20,00 & 35 & 10,00 & 35 & 10,00 & 0 & 0,00 & 63,00 & 37,00 \\
\hline Nordete Baiano & 53 & 7,00 & 33 & 8,00 & 27 & 10,00 & 4 & 5,00 & 2 & 6,00 & 20 & 6,00 & 20 & 6,00 & 0 & 0,00 & 62,00 & 38,00 \\
\hline Metropolitana & 295 & 40,00 & 119 & 31,00 & 73 & 26,00 & 40 & 50,00 & 6 & 17,00 & 175 & 50,00 & 174 & 50,00 & 0 & 0,00 & 40,00 & 60,00 \\
\hline Centro Sul & 117 & 16,00 & 70 & 18,00 & 54 & 20,00 & 11 & 14,00 & 5 & 14,00 & 47 & 13,00 & 47 & 13,00 & 0 & 0,00 & 60,00 & 40,00 \\
\hline Sul & 108 & 15,00 & 62 & 16,00 & 43 & 16,00 & 11 & 14,00 & 8 & 23,00 & 46 & 13,00 & 46 & 13,00 & 0 & 0,00 & 57,00 & 43,00 \\
\hline
\end{tabular}


Tabela 5 - Bahia: PIB, estoque médio de depósitos, estoque médio de créditos e razão crédito/débito por mesorregião - 2005

\begin{tabular}{l|c|c|c|c} 
de créditos e razão crédito/débito por mesorregião - 2005 & (\%) \\
\hline $\begin{array}{l}\text { Estado/ } \\
\text { Mesorregião }\end{array}$ & PIB & $\begin{array}{c}\text { Estoque } \\
\text { Médio } \\
\text { Depósito } \\
\text { (a) }\end{array}$ & $\begin{array}{c}\text { Estoque } \\
\text { Médio } \\
\text { Crédito } \\
\text { (b) }\end{array}$ & $\begin{array}{c}\text { (b)/(a) } \\
\mathbf{1 0 0}\end{array}$ \\
\hline BAHIA & 100,00 & 100,00 & 100,00 & 0,73 \\
\hline Oeste & 5,24 & 2,19 & 6,70 & 2,23 \\
\hline V. Sanfranciscano & 4,70 & 3,31 & 3,98 & 0,88 \\
\hline Centro Norte & 9,00 & 8,41 & 7,15 & 0,62 \\
\hline Nordeste Baiano & 5,13 & 3,96 & 3,13 & 0,58 \\
\hline Metropolitana & 54,94 & 65,52 & 59,43 & 0,66 \\
\hline Centro Sul & 9,79 & 8,28 & 7,50 & 0,66 \\
\hline Sul & 11,20 & 8,33 & 12,11 & 1,06 \\
\hline Fonte: Banco Central do Brasil/SISBACEN. Cálculos da autora.
\end{tabular}

sa área metropolitana. Portanto, é na praça correspondente à capital do estado onde se efetua grande parte das transações financeiras: a Salvador correspondem 91,63\% do estoque médio de depósitos e 93,74\% do estoque médio de créditos realizados no espaço da microrregião sob a sua liderança. Sob todos os aspectos, Salvador ocupa lugar privilegiado no ranking financeiro baiano (Banco Central/ SISBACEN). Não deixa de chamar a atenção, no entanto, o fato de que praças como Camaçari, Candeias e Simões Filho, que sediam importantes empreendimentos industriais, não alcancem participação significativa nas transações financeiras efetuadas no estado. Uma explicação para tal fato deve-se ao fato de as sedes regionais de grande parte das empresas instaladas nesses municípios estarem localizadas em Salvador, realizando, nessa praça, a parte mais significativa das suas transações financeiras, quando realizadas na Bahia. Mais que isso: presume-se que boa parte das transações financeiras das maiores empresas que operam na RMS seja realizada fora do espaço baiano.

Quando se observa a razão crédito/depósito, a mesorregião em foco atinge $0,66 \%$, abaixo da média apresentada para o estado. Esse dado revela que, no atual estágio do seu desenvolvimento, a atividade aqui implantada não tem sido capaz de alavancar créditos. Concluído o ciclo de industrialização - no qual a Bahia especializou-se na produção de produtos intermediários, ancorada no financiamento com base no sistema de incentivos fiscais -, a região não tem demonstrado diferenci- ais capazes de atrair investimentos de maior monta, que demandem volumes de créditos capazes de modificar tal relação. O fim de um ciclo e da institucionalidade que o sustentou, em particular a financeira, centrada no fornecimento de crédito pelos bancos públicos, tem dado lugar à política de isenções fiscais negociadas caso a caso e em competição direta com outros espaços, sem significativo rebatimento na oferta de créditos para o setor industrial.

A Mesorregião Oeste, detentora de 4,62\% do PIB baiano, detém apenas 2,19\% do estoque médio de depósitos e 6,70\% do estoque médio de créditos, e apresenta-se como a região onde o estoque médio de créditos é três vezes maior que o estoque médio de depósitos, com razão crédito/depósito da ordem de 2,64\%. O dinamismo da economia do Oeste baiano é ainda muito concentrado na microrregião liderada por Barreiras, responsável por três quartos do PIB mesorregional. Detém 57\% das agências bancárias, aproximadamente, $76 \%$ do estoque médio de depósitos e $90 \%$ do estoque médio de créditos de toda a mesorregião.

Nessa microrregião - com exceção do município de Catolândia, que não conta com agência bancária -, em todos os municípios, a razão crédito/ depósito é superior a 1. Numa primeira leitura, podese afirmar que se trata de um espaço cujo dinamismo econômico atrai recursos na forma de créditos. Acompanhando posição defendida por Amado (1998), vale observar que a análise desse indicador, de forma isolada, pode levar a erros, já que, em muitos casos, regiões que apresentam tal posição, na verdade, são exportadoras de capital: os créditos captados na região não voltam aos bancos nela instalados, na forma de depósitos. Ao contrário, migram para bancos situados fora da região, para os centros onde estão situadas as sedes das empresas que têm o espaço regional como lugar de produção, mas não de realização de transações financeiras.

O vale sanfranciscano constituí outro espaço do território baiano que, nas últimas décadas, passou por intenso processo de modernização da 
agricultura. Responsável por 4,70\% do PIB estadual, as agências implantadas na região representam, aproximadamente, $6 \%$ do total de agências no estado. No contexto dessa mesorregião, os municípios de Juazeiro e Paulo Afonso aparecem como as praças mais importantes, embora resultantes de dinâmicas distintas. Enquanto Juazeiro tem como base da sua economia a agricultura, o município de Paulo Afonso tem a sua atividade econômica relacionada à produção de energia elétrica. A praça de Juazeiro é responsável por 36,68\% do estoque médio de depósitos e $44,83 \%$ do estoque médio de créditos da região na qual está inserida. A participação de Paulo Afonso, ocupando o segundo lugar, é de $24,75 \%$ do estoque médio de depósitos e 18,98\% do estoque médio de créditos. Embora com participação sensivelmente menor, merece registro a praça de Bom Jesus da Lapa, com 10,39\% dos depósitos e 13\% dos créditos. Esse município, embora não tenha a mesma importância como centro econômico, como Juazeiro, integra a dinâmica do agronegócio.

Quando se toma a razão crédito/débito, cinco praças - Juazeiro (1,07), Curaçá $(1,48)$, Serra do Ramalho (1,82), Paratinga (1,56) e Ibotirama $(1,55)$ - apresentam posição superior a 1. Vale observar que todos esses municípios têm suas bases produtivas lastreadas pela agricultura irrigada.

A Mesorregião Sul, responsável por 11,27\% do PIB estadual, aparece como a segunda colocada no estoque médio de créditos, concentrando 12,10\% e $8,33 \%$ do estoque médio de depósitos . Essa mesorregião apresenta relação débito/crédito superior a 1. No contexto da mesorregião, o espaço comandado por Ilhéus e Itabuna, responde por $59,44 \%$ do estoque médio de depósitos e $67,80 \%$ do estoque médio de créditos. Nesse espaço, cinco municípios -Itabuna (1,78), Ibirapitanga (2,32), Ibirataia $(1,23)$, Ipiau $(1,20)$ e Camacã $(1,12)$-, todos produtores de cacau, têm razão crédito/depósito acima de 1.

A Microrregião de Porto Seguro, economicamente voltada pela produção de celulose e atividades turísticas em algumas cidades, aparece em segunda posição no contexto mesorregional, como detentora de 33,22\% do estoque médio de depósi- tos e $28,17 \%$ do estoque médio de créditos. Nesse espaço, municípios como Alcobaça $(1,02)$, Eunapólis $(1,08)$, Guaratinga (1,37), Itanhém $(1,21)$ e Medeiros Neto $(4,14)$ apresentam relação crédito/ depósitos superior a 1.

A Mesorregião Centro-Sul eCentro-Norte participam com 7,50\% e 7,15\% do estoque médio de crédito e com $8,28 \%$ e $8,41 \%$ do estoque médio de depósitos, respectivamente. A performance da Mesorregião Centro Norte deve-se, fundamentalmente, à praça de Feira de Santana, que concentra 51,81\% do total de estoque médio de depósitos e 47,10\% do estoque médio de créditos do total da mesorregião.

Já a Mesorregião Centro-Sul tem a praça de Vitória da Conquista como a mais importante, concentrando, aproximadamente, $25,00 \%$ do total dos estoques médios de créditos e depósitos no espaço em foco. Além dessa praça, destacam-se cidades que funcionam como "capitais regionais" em suas respectivas microrregiões, a exemplo das praças de Jequié, com 9,27\% e 10,40\%, e Guanambi, com $7,11 \%$ e $8,41 \%$ dos estoques médios de depósitos e de créditos, respectivamente.

A extensa área que constitui a Mesorregião Nordeste contribui com 5,13\% no total do PIB baiano. A participação da Mesorregião nas transações financeiras também é pouco expressiva: 3,96\% do estoque médio de depósitos; $3,13 \%$ do estoque médio de créditos. A razão depósito/crédito é de 0,58\%, a menor dentre todas as mesorregiões. A exceção da praça de Alagoinhas, nenhuma outra pontua com algum destaque no conjunto do estado.

\section{Principais praças financeiras}

Traduzindo a concentração espacial verificada na economia baiana, são poucas as praças que alcançaram estoques médios de depósitos e de créditos superiores a cem milhões de reais. Enquanto a classificação por depósitos - doze praças - reflete uma dinâmica onde as históricas "capitais regionais" pontuam entre as mais importantes, a classificação por estoque de crédito já evidencia um mapa financeiro onde os sinais do agronegócio se fazem presentes. 
Tabela 6 - Bahia: principais praças financeiras por estoque médio de depósitos e estoque médio de créditos - 2005

\begin{tabular}{|c|c|c|c|c|c|}
\hline & \multicolumn{2}{|c|}{ Estoque médio de depósito } & \multicolumn{3}{|c|}{ Estoque médio de crédito } \\
\hline & Valor R\$ & $\%$ & & Valor R\$ & $\%$ \\
\hline Bahia & $13.490 .471 .565,79$ & 100,00 & Bahia & $9.843 .989 .475,32$ & 100,00 \\
\hline Salvador & $7.644 .487 .862,25$ & 56,67 & Salvador & $5.268 .357 .839,67$ & 53,52 \\
\hline Feira de Santana & $587.733 .159,83$ & 7,69 & Itabuna & $533.253 .598,42$ & 5,42 \\
\hline Camaçari & $314.799 .408,42$ & 2,33 & Barreiras & $384.978 .014,67$ & 3,91 \\
\hline Itabuna & $298.823 .172,58$ & 2,22 & Feira de Santana & $331.624 .304,75$ & 3,37 \\
\hline V. da Conquista & $268.910 .669,92$ & 1,99 & V. da Conquista & $180.626 .384,08$ & 1,83 \\
\hline Ilhéus & $186.750 .943,58$ & 1,38 & Juazeiro & $175.746 .505,17$ & 1,79 \\
\hline Juazeiro & $164.056 .030,33$ & 1,22 & Camaçari & $137.409 .432,64$ & 1,40 \\
\hline Barreiras & $154.641 .456,75$ & 1,15 & Luis E. Magalhães & $122.999 .151,08$ & 1,25 \\
\hline Alagoinhas & $144.180 .081,83$ & 1,07 & Ilhéus & $122.877 .432,42$ & 1,25 \\
\hline Lauro de Freitas & $113.493 .955,75$ & 0,84 & Eunapólis & $101.196 .928,17$ & 1,03 \\
\hline Simões Filho & $112.133 .136,50$ & 0,83 & & & \\
\hline Paulo Afonso & $110.665 .263,58$ & 0,82 & & & \\
\hline Jequié & $103.655 .850,50$ & 0,77 & & & \\
\hline Total & $10.204 .330 .991,82$ & 75,64 & & 7.257.872.662,90 & 73,73 \\
\hline
\end{tabular}

Fonte: Banco Central do Brasil/SISBACEN. Cálculos da autora

\section{CONSIDERAÇÕES FINAIS}

A distribuição espacial da rede bancária e da atividade financeira acompanha o movimento de acumulação de capitais. É marcada, por um lado, pela tendência à concentração nos espaços hegemônicos do desenvolvimento regional, como o da Região Metropolitana de Salvador, que reúne o maior número de agências e de transações financeiras mais complexas e articuladas com empresas e instituições em diferentes pontos do país, controlando, assim, os fluxos de capitais. Verifica-se, por outro lado, ampliação e (ou) retração da presença dos bancos e da atividade financeira em espaços que não se constituem como os centros dinâmicos da economia. O desdobramento geográfico verificado nesse movimento de centralização e ausência de serviços não é indiferente à natureza dos processos históricos.

Ao longo do texto, foram destacados os marcos definidores do desenvolvimento econômico e a dinâmica espacial que os acompanhou. Foi ressaltada a importância da atividade de exploração e refino do petróleo para a definição do perfil do estado e da concentração da atividade industrial da RMS. Da mesma forma, foram destacadas a modernização da agricultura e o seu encadeamento com a indústria, em especial, nas fronteiriças regiões Sul e Oeste do estado. A cultura do cacau, mesmo não tendo alcançado maior integração com outros setores no espaço baiano, lastreia a economia de importante região no contexto baiano, constituindo relações diretas dessa região com fluxos de comércio internacional. Quando se tomam as relações intrarregionais, verifica-se que as articulações econômicas são débeis. A indústria segue complementar à implantada na Região Sudeste, e a produção agrícola baseia-se, em grande parte, em commodities para exportação.

A economia baiana, nesse trajeto, contou com forte aporte de créditos e incentivos fiscais e financeiros. Os bancos, nesse processo, cumpriram papel fundamental, tanto os bancos públicos, criados para dar suporte aos processos desenvolvimentistas, como os privados, de implantação nacional e (ou) regional. A distribuição das agências e a movimentação financeira - além do desempenho em termos de estoques médios de depósitos e de créditos -, concentradas em determinados espaços, constituem parte da dinâmica econômica e da espacialidade que a caracteriza.

(Recebido para publicação em novembro de 2008) (Aceito em março de 2009) 


\section{REFERÊNCIAS}

ALMEIDA, Paulo Henrique. A economia de Salvador e a formação da sua Região Metropolitana. In: CARVALHO, Inaiá; PEREIRA, G. Corso (Org). Como anda Salvador. Salvador: EDUFBa, 2008.

AMADO, Adriana. Impactos regionais do recente processo de concentração bancária no Brasil. In: ENCONTRO NACIONAL DE ECONOMIA POLÍTICA, 3, 1998, Niterói, Anais... Niterói,RJ., ANPEC, 1998. v. 2.

A questão regional e o sistema financeiro do Brasil: uma interpretação pós-keynesiana. In: ENCONTRO NACIONAL DE ECONOMIA, 14, 1996, Rio de Janeiro. Anais... Rio de Janeiro: ANPEC, 1996.

AZEVEDO, J. Sérgio Gabrielli. Economia e mercado de trabalho na Bahia e RMS: uma abordagem de longo prazo. Bahia: Análise \& Dados, Salvador, SEI, v.10, n.1, p.49-67, jun. 2000.

BAHIA. Secretaria de Indústria e Comércio. A indústria no Estado da Bahia: uma proposta de política industrial. Salvador, 1983.

CAVALCANTI, L. Ricardo Mattos Teixeira. Crédito e desenvolvimento regional: o caso do Banco de Desenvolvimento do Estado da Bahia. 2004. Tese (Doutorado) - Escola de Administração da Universidade Federal da Bahia. Salvador, 2004

CARVALHO, C. E.; VIDOTTO, C. A. Abertura do setor bancário ao capital estrangeiro nos anos 1990: os objetivos e o discurso do governo e dos banqueiros. Nova Economia, Belo Horizonte, v.17, n.3, p.395-425, set./dez. 2007.

CLAN S. A. Consultoria e Planejamento. Avaliação de impacto da demanda de equipamentos e materiais pela indústria química com implantação programada na Bahia. Salvador, 1973.

CORRÊA, Vanessa Petrelli. Distribuição de agências bancárias e concentração financeira nas praças de maior dinamismo econômico - um estudo dos anos 1980 e 1990 In: CROCCO, Marco; JAYME JR., Frederico G. (Org.) Moeda e território: uma interpretação da dinâmica regional brasileira. Belo Horizonte: Autêntica, 2006.

CORRÊA, Roberto Lobato. Concentração bancária e os centros de gestão do território. In: . (Org.) Estudos sobre a rede urbana. Rio de Janeiro: Bertrand Brasil, 2006.

DIAS, Leila Christina. Por que os bancos são o melhor negócio no país? In: ALBUQUERQUE, Edu Silvestre (Org.) Que país é esse? São Paulo: Globo, 2005.

. Réseaux d'information et urbain au Brésil. Paris: L'Harmattan, 1995.

CROCCO, Marco; FIGUEIREDO, A. T. Lanna. Estratégias bancárias diferenciadas no território: uma análise exploratória. In: ENCONTRO NACIONAL SOCIEDADE DE ECONOMIA POLITICA,13, 2008, João Pessoa.

; RUIZ, Ricardo; CAVALCANTE, Anderson. Redes e polarização urbana e financeira: uma exploração inicial para o Brasil. In: ENCONTRO NACIONAL SOCIEDADE DE ECONOMIA POLITICA, 13, 2008, João Pessoa.

ELIAS, Denise. Agronegócio e desigualdades socioespaciais. In. ELIAS, Denise; PEQUENO, Renato. Difusão do agronegócio e novas dinâmicas socioespaciais. Fortaleza: Banco do Nordeste, 2006.

FERNANDES, C. Monteiro. Complexo coureiro-calçadista: uma indústria promissora. In: Superintendência de Estudos Econômicos e Sociais da Bahia. Dez anos de economia baiana. Salvador: SEI, 2002.
FREITAS, A. F. Guerreiro de. "Eu vou para a Bahia": a construção da regionalidade contemporânea. Bahia: Análise \& Dados, Salvador, v.9, n.4, p.49-67, mar. 2000.

FIBGE. Fundação Instituto Brasileiro de Geografia e Estatística. Censo Industrial de 1980. Rio de Janeiro, 1980.

Fundação Instituto Brasileiro de Geografia e Estatística. Censo Industrial de 1950. Rio de Janeiro, 1950.

GONÇALVES, Reinaldo. Globalização e desnacionalização. Rio de Janeiro: Paz e Terra, 1999.

HANNEQUIM, Ruth Maria. A estrutura da rede bancária no estado da Bahia. In. SANTOS FILHO, Milton (Org.) Bahia: questões financeiras atuais. Salvador: Faculdade de Ciências Econômicas/UFBA, 1989. p. 165-205.

HARVEY, David. A geopolítica do capitalismo. In: A produção capitalista do espaço. São Paulo: Annablume, 2005.

KRAYCHETE, Elsa Sousa. A geografia financeira do Estado da Bahia: 1995-2004. In: RIBEIRO, Maria Teresa Franco; MILANI, Carlos R. S. Compreendendo a complexidade sócio-espacial contemporânea: o território como categoria de diálogo interdisciplinar, Salvador; EDUFBa, 2009

. A indústria na Bahia em 1980: uma interpretação a partir de ramos industriais e seções produtivas. 1988. Dissertação (Mestrado) - Faculdade de Ciências Econômicas da Universidade Federal da Bahia. Salvador, 1988.

LABASSE, Jean. L'espace financier. Paris: Armand Colin, 1974.

LEYSHON, A.; THRIFT, N. Money/space: geographies of monetary transformation. London: Routledge, 1997.

LIMA, Adelaide Motta de. Bancos comerciais estaduais e intervenção econômica do Estado brasileiro: a atuação do Banco do Estado da Bahia entre 1960 e 1986. Tese (Doutorado em Administração) - Escola de Administração, Universidade Federal da Bahia. Salvador, 2001.

OLIVEIRA, Francisco. As contradiç̃es do ão: globalização, nação, região, metropolização. In: DINIZ, Clélio Campolina; CROCCO, Marcos. Economia regional e urbana: contribuições teóricas recentes. Belo Horizonte: Editora da UFMG, 2006.

O elo perdido: classe e identidade de classe na Bahia. São Paulo: Editora Fundação Perseu Abramo, 2003.

OLIVEIRA, Nelson. Investimento de pauperização: números da miséria em sub-regióes da Bahia. Cadernos do CEAS, Salvador, n.176, p.37-58, jul./ago. 1998.

PORTO, Edgar. Descentralização espacial e concentração econômica na Bahia. Superintendência de Estudos Econômicos e Sociais da Bahia. Dez anos de economia baiana. Salvador: SEI, 2002. (Série estudos e pesquisas).

RITZ, A. As exportações internacionais e interregionais no desenvolvimento baiano (1950-1969). Salvador: Faculdade de Ciências Econômicas da UFBA, 1972.

SAMPAIO, F. T. Aspectos da regionalização do desenvolvimento industrial: o caso baiano. 1974. Tese (Concurso de Professor Assistente) - Faculdade de Ciências Econômicas da Universidade Federal da Bahia. Salvador, 1974.

SANTOS. Milton. O papel metropolitano da cidade de Salvador. Revista Brasileira dos Municípios, Rio de Janeiro, Conselho Nacional de Estatística, v.9 n.35/36, 1954.

TAVARES, M. da C. Natureza e contradições do desenvolvimento financeiro recente. In: Da substituição de importações ao capitalismo financeiro: ensaios sobre a economia brasileira. Rio de Janeiro: Zahar Editores, 1976. 


\section{BANKS AND CREDIT IN BAHIA'S RECENT DEVELOPMENT}

\author{
Elsa Sousa Kraychete
}

Based on the space distribution of bank branches and indicative of deposits and credits, this paper presents the financial geography of the state of Bahia in 2005 The recent trajectory of Bahian economy is examined to compare the reading of these data, pointing out the role of banks and the increment of credit as fundamental for the regional development. Finally, based in data from Brazil's Central Bank, the relative position of Bahia compared to the main Brazilian banking business centers is presented, the chains of bank branches, the covering of Bahia territory by bank branches, the spatial distribution of the medium size of deposits and credits and the financial hierarchization of the main business centers. In this way this paper tries to establish connections between the regional financial dynamics with thereespatialization of those activities, associated to the nature of the cycles of economic accumulation.

KEYwORDS: development, territory, banks, credit, Bahia.

\section{BANQUES ET CRÉDITS DANS LE DÉVELOPPEMENT RÉCENT DE BAHIA}

\author{
Elsa Sousa Kraychete
}

C'est à partir de la répartition spatiale des agences bancaires et des indicateurs de dépôts et de crédits que nous présentons la géographie financière de l'Etat de Bahia en 2005. Pour consolider l'analyse des données, nous reprenons une trajectoire récente de l'économie bahianaise pour mettre ensuite en évidence le rôle des banques et l'apport du crédit en tant qu'éléments fondamentaux pour le développement régional. Enfin, les données de la Banque Centrale nous permettent de présenter la position relative à Bahia face aux principales places bancaires brésiliennes, au réseau d'agences, à la couverture du territoire bahianais par les agences bancaires, à la distribution spatiale des stocks moyens de dépôts et de crédits et à la hiérarchisation financière des principaux endroits. L'article cherche encore à établir les rapports entre la dynamique financière régionale et la re-spatialisation de ces activités, associées à la nature des cycles de l'accumulation de l'économie.

Mots-CLÉs: développement, territoire, banques, crédit, Bahia.

Elsa Sousa Kraychete - Economista. Doutora em administração pela Universidade Federal da Bahia. Professora do Programa de Pós-graduação em Planejamento Territorial e Desenvolvimento Social da Universidade Católica do Salvador. Dedica-se ao estudo e pesquisa de temas ligados á questão do desenvolvimento e das desigualdades. Dentre as publicações mais recentes destacam-se: A geografia financeira do estado da Bahia: 1995 - 2004. In: RIBEIRO, Maria Tereza Franco; MILANI, Carlos Roberto Sanchez (Org.). Compreendendo a complexidade sócioespacial contemporânea: o território como categoria de diálogo interdisciplinar. Salvador: EDUFBa, 2009; Modelo de Desenvolvimento e Pacto Social. Bahia Análise \& Dados, v. 17, p. 1135-1145, 2008; Desenvolvimento: razões e limites do discurso do Banco Mundial. Cadernos do CRH (UFBA), v. 19, p. 415-430, 2006. 